\title{
MICROBIAL DIVERSITY AND PHYSICO- CHEMICAL ASSESSMENT OF LAKE WATER
}

\author{
Siddharth Birla \\ Department of Biotechnology \\ Padmashree Institute of Management and Sciences, \\ Bengaluru, Karnataka, India
}

\begin{abstract}
Qualitative assessment of lake water in nearby rural as well as urban areas of Kengeri locality (Bangalore city) was undertaken on a moderate level in the following study. The problem investigated was poor condition of lakes as they were not maintained well thus the water was not in the condition of direct consumption. We used different methods for the assessment like $\mathrm{pH}$ of water, odor, BOD or DO, COD estimation of coliforms by MPN, and microbial examination by spread plate method. As a result, we found that lake Byrohalli was the cleanest of all with highest DO of $3.6 \mathrm{mg} / \mathrm{L}$ after incubation, whereas other two lakes displayed zero dissolved oxygen. COD of lake Byrohalli was least at $0.8 \mathrm{mg} / \mathrm{L}$, while Kommaghatta and Mallathalli had $1.6 \mathrm{mg} / \mathrm{L}$ and $3.2 \mathrm{mg} / \mathrm{L}$ respectively. Also the MPN index of Byrohalli lake was least i.e., $350 / 100 \mathrm{ml}$, while that of Kommaghatta was 540/100ml and Mallathalli with highest index of $1600 / 100 \mathrm{ml}$. The microbial diversity in bacterial forms was found to be highest in lake Mallathalli followed by Kommaghatta and the least in lake Byrohalli.
\end{abstract}

Keywords - Chemical oxygen demand (COD), Biochemical oxygen demand (BOD), Dissolved oxygen (DO), Most probable number (MPN), coliforms.

\section{INTRODUCTION}

The estimation of species surrounding the lake, seasonal variations in terms of time period and range of extremes along with the discharge of effluent into the water body is important with regards to a lake in fragile environment. (El-Serehy et al., 2018)

Introduction of non-indigenous species, chemical pollutants, and climate changes along with usage of land can change the physical and chemical composition of a lake. This may also lead to destruction of the naturally available organisms in and near lake like phytoplankton cultural also leading to eutrophication. (Allinger and Reavie, 2013). A man-made lake can be sometimes potentially dangerous as it attracts the pathogens and parasites and other invasions. (Carolus et al., 2019)

Eutrophication is a constant reason of lake deaths and a widespread environmental problem. Sometimes the lakes

\author{
Dr. Vedashree $S$ \\ Department of Microbiology \\ Padmashree Institute of Management and Sciences, \\ Bengaluru, Karnataka, India
}

recover when nutrient influx is lowered. Also lowered influx of phosphorus from soils may be useful save lakes from eutrophication in agricultural regions. As this type of eutrophication is unchangeable without proper soil management. (Carpenter, 2005)

Reducing phosphorus disposal into lakes is a key rescue tool for controlling Lake Eutrophication. Increased inputs of phosphorus into water bodies degrades water quality and reduce the oxygen levels in central basin hypolimnetic which, in turn, eliminates the thermal habitat mandatory to cold-water organisms and contributes to the removal of important benthic prey species of the fishes. (Scavia et al., 2014)

The degradation of aquatic ecosystems due to nutrient enrichment results in excessive cyanobacterial water blooms. It is a serious global problem that may render ecosystem as well as health at risks. Significant amount of research and experimentation has been made possible to recognize the wide range of toxins produced by cyanobacteria. (Bláha et al., 2009) The enrichment of water bodies by nutrients have a significantly large impact on the magnitude of predator avoidance. (Turner and Chislock, 2010)

The north temperate regions contains the lakes of highest densities on earth which are threatened by chloride run-off and ever increasing urban settlements that are salinizing the lake freshwaters and there by deteriorate water quality and ecosystem services provided by lakes. (Dugan et al., 2017)

Proper measures needs to be taken to control phosphorus related eutrophication by using sediments having high affinity towards phosphorus is expected to be helpful in subsiding the ageing process of lakes. (Schindler, 1974)

\section{METHODOLOGY}

\section{A. Sample Collection}

Lake water samples were collected from three different lakes in the vicinity of Kengeri namely; Mallathalli Lake, Byrohalli Lake and Kommaghatta Lake.

The samples were directly collected into BOD bottles and were taken to the laboratory for further examination. 
Published Online February 2020 in IJEAST (http://www.ijeast.com)

\section{B. Physical examination}

$\mathrm{PH}$ of the collected samples was measured using $\mathbf{p H}$ meter.

The odour of the sample was noted down.

\section{Chemical Examination}

Chemical examination was carried out using methods for estimation of Dissolved Oxygen (DO) (Aneja, 2007) (Verma and Singh, 2012) (Brookman, 1997), (Apha-biochemicaloxygen-demand-white-paper) and Chemical Oxygen Demand (COD) (Aneja, 2007) (Pisarevsky, 2005) (Hur et al., 2010) (Canelli et al., 1976) (Rho et al., 2018) (Determination of Chemical Oxygen Demand in Waters and Effluents, 1998)

\section{Microbial examination}

The Isolation of microbes by spread plate method, Standard plate count (SPC), and Most Probable Number (MPN) (Aneja, 2007), (Ahmad et al., 2017) method were carried out as a part of microbial examination along with gram staining. (Gyure, 2010) (Bartholomew and Mittwer, 1952), (ASM.org)

\section{EXPERIMENT AND RESULT}

A. Physical Examination

\subsection{1) Noted pH}

\begin{tabular}{|c|c|}
\hline LAKE & $\mathbf{p H}$ \\
\hline Byrohalli & 7.36 \\
\hline Mallathalli & 7.83 \\
\hline Kommaghatta & 7.99 \\
\hline
\end{tabular}

Table: $1.0 \mathrm{pH}$ of the water samples tested

\subsection{2) Odor}

At the time of water sample collection only Mallathalli sample was having bad odor.

Rest of the sample were odorless.

\section{B. Chemical Examination}

3.2.1) Dissolved Oxygen (DO): The surface water designated as cold-water fisheries must meet a minimum dissolved oxygen standard of $7 \mathrm{mg} / \mathrm{L}$, surface water protected for warm water fish and aquatic life must meet a minimum DO of $5 \mathrm{mg} / \mathrm{L}$. DO levels of around $100 \%$ saturation are good for aquatic life. (Michigan Water Quality Standards)

\begin{tabular}{|l|l|l|l|}
\hline Fresh Sample & DO $(\mathrm{mg} / \mathrm{L})$ & $\begin{array}{l}\text { DO after } \\
\text { incubation }(\mathrm{mg} / \mathrm{L})\end{array}$ & BOD $(\mathrm{mg} / \mathrm{L})$ \\
\hline Byrohalli & 5.46 & 3.6 & 1.86 \\
\hline Mallathalli & 4.4 & 0 & 4.4 \\
\hline Kommaghatta & 4.92 & 0 & 4.92 \\
\hline
\end{tabular}

Table: 2.0 Dissolved oxygen of the water samples tested

3.2.2) Chemical Oxygen Demand (COD) of samples was measured and calculated.

\begin{tabular}{|c|c|}
\hline SAMPLE & COD $(\mathrm{mg} / \mathrm{L})$ \\
\hline Distilled water & 0 \\
\hline Byrohalli lake & 0.8 \\
\hline Kommaghatta lake & 1.6 \\
\hline Mallathalli lake & 3.2 \\
\hline
\end{tabular}

Table: 3.0 COD of the water samples tested

\section{Microbial Examination}

[Here S-small, M-medium, L-large, P-pin head]

Table: 4.0 Microbial Examination of water sample from lake Kommaghatta

\begin{tabular}{|c|c|c|c|c|c|c|c|}
\hline $10^{-1}$ & $\begin{array}{l}\text { CO } \\
\text { LO } \\
\text { R }\end{array}$ & $\begin{array}{l}\mathbf{S I} \\
\mathbf{Z} \\
\mathbf{E}\end{array}$ & $\begin{array}{l}\text { APPEA } \\
\text { R } \\
\text { ANCE }\end{array}$ & $\begin{array}{l}\text { ELEV } \\
\text { A } \\
\text { TION }\end{array}$ & $\begin{array}{l}\text { VISIBILI } \\
\text { TY }\end{array}$ & $\begin{array}{l}\text { MARGI } \\
\mathbf{N}\end{array}$ & $\begin{array}{l}\text { GRAM } \\
\text { STAINING }\end{array}$ \\
\hline & $\begin{array}{l}\text { Yell } \\
\text { ow(5 } \\
\end{array}$ & $\begin{array}{l}\mathrm{S} \\
\mathrm{M}\end{array}$ & Smooth & Raised & Opaque & Irregular & $\begin{array}{l}\text { Gram } \\
\text { negative } \\
\text { coccus }\end{array}$ \\
\hline & $\begin{array}{l}\text { Pale } \\
\text { yello } \\
\mathrm{w}(20 \\
9)\end{array}$ & $\mathrm{S}$ & Smooth & Raised & Opaque & Regular & $\begin{array}{l}\text { Gram } \\
\text { negative } \\
\text { coccus }\end{array}$ \\
\hline & $\begin{array}{l}\text { Oran } \\
\text { ge } \\
(5) \\
\end{array}$ & $\mathrm{M}$ & Smooth & Raised & Opaque & Circular & $\begin{array}{l}\text { Gram } \\
\text { negative rods }\end{array}$ \\
\hline & $\begin{array}{l}\text { Crea } \\
\mathrm{m}(1 \\
14)\end{array}$ & $\mathrm{M}$ & Smooth & Raised & Opaque & $\begin{array}{l}\text { Irreg., } \\
\text { circular, } \\
\text { Wrinkle } \\
\text { d }\end{array}$ & $\begin{array}{l}\text { Gram } \\
\text { negative rods }\end{array}$ \\
\hline $10^{-2}$ & $\begin{array}{l}\text { Crea } \\
\mathrm{m}(3)\end{array}$ & $S$ & Smooth & Flat & Opaque & Circular & $\begin{array}{l}\text { Gram } \\
\text { negative } \\
\text { coccus }\end{array}$ \\
\hline $10^{-3}$ & $\begin{array}{l}\text { Crea } \\
\mathrm{m}(1)\end{array}$ & M & Smooth & Flat & Opaque & Circular & $\begin{array}{l}\text { Gram } \\
\text { positive rods }\end{array}$ \\
\hline
\end{tabular}


International Journal of Engineering Applied Sciences and Technology, 2020

Vol. 4, Issue 10, ISSN No. 2455-2143, Pages 59-64

Published Online February 2020 in IJEAST (http://www.ijeast.com)

\begin{tabular}{|l|c|c|c|c|c|c|c|}
\hline $\begin{array}{l}10^{-} \\
1\end{array}$ & Cream(11) & M,S, & Smooth & Flat & Opaque & Circular & $\begin{array}{c}\text { Gram } \\
\text { negative } \\
\text { rods }\end{array}$ \\
\hline $\begin{array}{l}10^{-} \\
2\end{array}$ & Cream(1) & L & Smooth & Flat & Opaque & Irregular & $\begin{array}{c}\text { Gram } \\
\text { negative } \\
\text { rods }\end{array}$ \\
\hline Yellow(1) & L & Rough & Raised & Opaque & Circular & $\begin{array}{c}\text { Gram } \\
\text { negative } \\
\text { coccus }\end{array}$ \\
\hline
\end{tabular}

Table: 5.0 Microbial Examination of water sample from lake Byrohalli

\begin{tabular}{|c|c|c|c|c|c|c|c|}
\hline $10^{-1}$ & $\begin{array}{l}\text { Orange } \\
(72)\end{array}$ & $\mathrm{M}, \mathrm{S}$ & Smooth & Raised & Opaque & $\begin{array}{l}\text { Irregular } \\
\text { Circular }\end{array}$ & $\begin{array}{l}\text { Gram } \\
\text { negativ } \\
\text { e rods }\end{array}$ \\
\hline & $\begin{array}{l}\text { Cream }(22 \\
0)\end{array}$ & $\begin{array}{l}\mathrm{M}, \\
\mathrm{S}, \mathrm{P}\end{array}$ & Smooth & Flat & Opaque & $\begin{array}{l}\text { Irregular, } \\
\text { Circular }\end{array}$ & $\begin{array}{l}\text { Gram } \\
\text { negativ } \\
\text { e rods }\end{array}$ \\
\hline & $\begin{array}{l}\text { White(24 } \\
\text { ) }\end{array}$ & $\begin{array}{l}\mathrm{L}, \mathrm{M} \\
\mathrm{S}\end{array}$ & Smooth & $\begin{array}{l}\text { Raised, } \\
\text { Flat }\end{array}$ & Opaque & Irregular & $\begin{array}{l}\text { Gram } \\
\text { negativ } \\
\text { e rods }\end{array}$ \\
\hline $10^{-2}$ & $\begin{array}{l}\text { Orange }(8 \\
\text { ) }\end{array}$ & $\mathrm{M}$ & Smooth & Flat & Opaque & Irregular & $\begin{array}{l}\text { Gram } \\
\text { positive } \\
\text { coccus }\end{array}$ \\
\hline & $\begin{array}{l}\text { Orangish } \\
\text { White } \\
(23)\end{array}$ & $\mathrm{M}, \mathrm{S}$ & Smooth & Flat & Opaque & $\begin{array}{l}\text { Irregular, } \\
\text { Circular, } \\
\text { Wrinkled }\end{array}$ & $\begin{array}{l}\text { Gram } \\
\text { negativ } \\
\text { e rods }\end{array}$ \\
\hline & $\begin{array}{l}\text { Cream }(33 \\
\text { ) }\end{array}$ & $\mathrm{S}, \mathrm{P}$ & Smooth & Flat & Opaque & Circular & $\begin{array}{l}\text { Gram } \\
\text { negativ } \\
\text { e rods }\end{array}$ \\
\hline $10^{-3}$ & Cream (9) & $\mathrm{M}, \mathrm{S}$ & Smooth & Flat & Opaque & Circular & $\begin{array}{l}\text { Gram } \\
\text { negativ } \\
\text { e rods }\end{array}$ \\
\hline $10^{-4}$ & $\begin{array}{l}\text { Yellow } \\
\text { (1) }\end{array}$ & $\mathrm{M}$ & Rough & Raised & Opaque & Irregular & $\begin{array}{l}\text { Gram } \\
\text { negativ } \\
\mathrm{e} \\
\text { coccus }\end{array}$ \\
\hline & Cream (1) & $\mathrm{L}$ & Smooth & Flat & Opaque & Irregular & $\begin{array}{l}\text { Gram } \\
\text { negativ } \\
\text { e rods }\end{array}$ \\
\hline
\end{tabular}

Table: 6.0 Microbial Examination of water sample from lake Mallathalli

\section{Most Probable Number (MPN)}

Note: Color change denote acid is produced by microbe.

\begin{tabular}{|l|c|l|l|l|}
\hline Byrohalli & $10 \mathrm{ml}$ & $1 \mathrm{ml}$ & $0.1 \mathrm{ml}$ & $\begin{array}{l}\text { MPN } \\
\text { index/100ml }\end{array}$ \\
\hline Color change & $5 / 5$ & $4 / 5$ & $1 / 5$ & \\
\hline $\begin{array}{l}\text { Gas } \\
\text { Production }\end{array}$ & $5 / 5$ & $5 / 5$ & $1 / 5$ & 350 \\
\hline Mallathalli & & & & \\
\hline
\end{tabular}

\begin{tabular}{|c|c|c|c|c|}
\hline Color change & $5 / 5$ & $5 / 5$ & $3 / 5$ & \\
\hline $\begin{array}{l}\text { Gas } \\
\text { Production }\end{array}$ & $5 / 5$ & $5 / 5$ & $5 / 5$ & 1600 \\
\hline Kommaghatta & & & & \\
\hline Color change & $5 / 5$ & $5 / 5$ & $4 / 5$ & \\
\hline $\begin{array}{l}\text { Gas } \\
\text { Production }\end{array}$ & $5 / 5$ & $5 / 5$ & $2 / 5$ & 540 \\
\hline
\end{tabular}

Table: 7.0 MPN index of the water samples tested

\section{DiscusSION}

Lakes are the important source of fresh water and several microbes, plants, animals thrive on its water. These natural or man-made water bodies are in plenty in number [167+ according to $(\boldsymbol{B B M P})]$ in the city of Bangalore, but it is a matter of concern that most of them are not in a good condition. The increasing population and rapid urbanization of the city is posing a serious threat to the lakes, some of them have been completely killed (filled up with mud) in order to provide space to make residential building; thus the health of lakes have become a serious issue in the developing smart cities. Study of nearby lakes namely Byrohalli lake, Kommaghatta lake and Mallathalli lake in the vicinity of Kengeri, Bangalore was carried out to check the water quality by performing certain examinations on water samples. Since the above mentioned lakes are inside the city; they are free from industrial pollution. The sample collection was done in the month of February which is not much hot climate in Bangalore city. Even these are not disposed with any kind of human wastes. Although all of these are having metal wire fencing, only two (Kommaghatta and Byrohalli) of them are well maintained, lake Mallathalli was not in good condition; water was stinking with algal bloom on sides. It was dark in color due to improper maintenance and some human interference. It was a mess to collect water sample from that lake. On the other hand, Lake Kommaghatta was well maintained with a proper fencing surrounded by lush green garden having beautiful and rare type of flower, tree and bush variety. It is also used for fishing purpose and we were able to see birds from dinosaur era. Lake Byrohalli did not had much greenery around but it had very clean water which was pulled up using bore wells and sent to nearby areas for water supply. The water samples were collected from these lakes and were examined for various tests like $\mathrm{pH}$, odour, DO, COD and MPN. Also, the spread plating after serially diluting the samples was done for the identification and isolation of various microbial forms. 


\section{International Journal of Engineering Applied Sciences and Technology, 2020 \\ Vol. 4, Issue 10, ISSN No. 2455-2143, Pages 59-64 \\ Published Online February 2020 in IJEAST (http://www.ijeast.com)}

On considering and comparing our work with previous studies, it can be surely said that the obtained DO values do not meet the standard minimum requirements as only Byrohalli lake had DO of $5.46 \mathrm{mg} / \mathrm{L}$ which is just on the border line as compared to the DO levels recorded at lake Mallital $7.9 \mathrm{mg} / \mathrm{L}$ to $8.6 \mathrm{mg} / \mathrm{L}$ of Nanital (Sharma, 2014) city whereas the BOD levels were as low as $2.8 \mathrm{mg} / \mathrm{L}$ to $3.5 \mathrm{mg} / \mathrm{L}$ which is as good as the BOD $1.86 \mathrm{mg} / \mathrm{L}$ (Table 2.0) of lake Byrohalli. The 24DO levels of some of the urban lakes in Thane (Nabar et al., 2014) district were $6 \mathrm{mg} / \mathrm{L}, 5 \mathrm{mg} / \mathrm{L}, 4, \mathrm{mg} / \mathrm{L}$ with the BOD values of $2 \mathrm{mg} / \mathrm{L}$, $3 \mathrm{mg} / \mathrm{L}, 3 \mathrm{mg} / \mathrm{L}$ respectively with a $\mathrm{pH}$ of range 6.5 to 8.5 .

According to Indian standard the BOD of $3 \mathrm{mg} / \mathrm{L}$ to $5 \mathrm{mg} / \mathrm{L}$ (BIS, 1991) is considered good enough. The other two lakes of Mallathalli and Kommaghatta were having BOD of $4.4 \mathrm{mg} / \mathrm{L}$ and $4.92 \mathrm{mg} / \mathrm{L}$ (Table 2.0 ) respectively, which is comparatively very less than that of the lakes of Chennai (K.Raji and Abraham , 2018) ranging from 9 to $34 \mathrm{mg} / \mathrm{L}$ of BOD. One recent study in Lalbagh (Gorain et al., 2018) lake of Bengaluru city was found to be contaminated excessively with heavy metals due to immersion of religious idols leading its BOD and COD from 17.5 and 135.5 to 27.4 and $237.5 \mathrm{mg} / \mathrm{L}$ respectively. On the other hand, COD values ranged from 0.8 to $3.2 \mathrm{mg} / \mathrm{L}$ (Table 3.0) which is very less as compared to other lakes studied by different people which ranged up to $104.11 \mathrm{mg} / \mathrm{L}$ in case of Ramgarh lake (Barnwal et al., 2015), Gorakhpur, U.P. Lakes of Chennai ranging from $12.8 \mathrm{mg} / \mathrm{L}$ to $102 \mathrm{mg} / \mathrm{L}$ kind of high scale variations. $\mathrm{pH}$ noted was fairly ok in the range of 7 to 8 (Table 1.0) which is almost neutral; as $\mathrm{pH}$ (Road and Grove 2004) 6 to 9 is recommended good for aquatic life. Also the $\mathrm{pH}$ at Bitter lake (El-Serehy et al., 2018) was around 8.04 to 8.30 and lakes of Chennai ranged from 6.1 to 8.87 .

Microbial examination(MPN) (Aneja, 2007) (Ahmad et al., 2017) obtained was very high which denotes that the water contained high number of Coliforms in case of lake Mallathalli with MPN equal to $1600 / 100 \mathrm{ml}$ (Table 7.0) water followed by Kommaghatta lake with 540/100ml (Table 7.0) range and the least polluted was found to be Byrohalli lake with $350 / 100 \mathrm{ml}$ (Table 7.0) vaFlue at standard MPN index which can be compared with the MPN range of Chennai lakes from $34 / 100 \mathrm{ml}$ to $/ 900 / 100 \mathrm{ml}$ and that of in lakes of Thane district was 50/100ml, 500/100ml, and 5000/100ml. Also a significant of gram negative colonies of bacteria (rods and coccus) were obtained which gives a rough picture of lake water quality (Table 4, 5, 6).

\section{CONCLUSION}

The results of the current study indicated that the lakes of Mallathalli and Kommaghatta were in bad condition in terms of its water quality as they are in closer proximity to the city thus, affecting all the life forms linked to them, while lake Byrohalli (in outskirts of city) was in much good condition as compared to the other two lakes.
Impurities in the lake water causes degradation of water quality. As the summer approach; lake spoiling parameters increases while it decreases/dilutes in rainy season. This increases the nitrogen content simultaneously causing more microbial growth and thus leading to eutrophication of lake. This leads to depletion of oxygen in water which kills the fishes that feed on malarial larvae causing outburst of disease. Also, the microbes at the bottom of lake cannot degrade the waste as there is lack of oxygen in water. These are very common problems for every lake ecosystem, mostly due to human activities and sometime due to natural ageing; lakes die. To overcome these problems serious steps, need to be taken like proper treatment of waste water before releasing it into water, regular checking of water quality and aquatic life in water. Strict rules against breaking of water pollution laws, prohibition of discharge of any kind of waste into water bodies. In country like India, there is a one major practice of discharge of religious offerings into water bodies. This is practiced all over the country in the name of faith. To stop these practices, people need to be educated about the effects because even if the government does cleaning of water bodies (as it happened in case of river Ganga cleaning) or our locality it is our duty to maintain it clean. Millions of rupees was spent on cleaning of Ganga water but still it is not clean. This cannot be achieved by one person or a group of people, everyone needs to do their part in keeping surroundings clean; be it air, land or water as at the end everything gets stuffed into the water bodies.

\section{ACKNOWLEDGEMENT}

I would like to acknowledge the uninterrupted help and support from Padmashree Institute of Management and Sciences during the project duration.

\section{REFERENCE}

[1] Aneja, K. R. (2007). Experiments in microbiology, plant pathology and biotechnology. New Age International..

[2] Gram Stain Protocols. (n.d.). ASM.Org. Retrieved February 18, 2020, from https://www.asm.org/Protocols/Gram-Stain-Protocols

[3] EGLE - Michigan Water Quality Standards. (n.d.). Retrieved February 18, 2020, from https://www.michigan.gov/egle/0,9429,7-1353313_3681_3686_3728-350340--,00.html

[4] Pisarevsky, A. M., Polozova, I. P., \& Hockridge, P. M. (2005). Chemical Oxygen Demand. Russian Journal of Applied Chemistry, 78(1), 101-107. https://doi.org/10.1007/s11167-005-0239-6

[5] The Determination of Chemical Oxygen Demand in Waters and Effluents 1998. (n.d.). 66.

[6] El-Serehy, H. A., Abdallah, H. S., Al-Misned, F. A., Irshad, R., Al-Farraj, S. A., \& Almalki, E. S. (2018). Aquatic ecosystem health and trophic status 


\section{International Journal of Engineering Applied Sciences and Technology, 2020 \\ Vol. 4, Issue 10, ISSN No. 2455-2143, Pages 59-64 \\ Published Online February 2020 in IJEAST (http://www.ijeast.com)}

classification of the Bitter Lakes along the main connecting link between the Red Sea and the Mediterranean. Saudi Journal of Biological Sciences, 25(2), 204-212. https://doi.org/10.1016/j.sjbs.2017.12.004

[7] Allinger, L. E., \& Reavie, E. D. (2013). The ecological history of Lake Erie as recorded by the phytoplankton community. Journal of Great Lakes Research, 39(3), 365-382. https://doi.org/10.1016/j.jglr.2013.06.014

[8] Dugan, H. A., Bartlett, S. L., Burke, S. M., Doubek, J. P., Krivak-Tetley, F. E., Skaff, N. K., Summers, J. C., Farrell, K. J., McCullough, I. M., Morales-Williams, A. M., Roberts, D. C., Ouyang, Z., Scordo, F., Hanson, P. C., \& Weathers, K. C. (2017). Salting our freshwater lakes. Proceedings of the National Academy of Sciences, 114(17), 4453-4458. https://doi.org/10.1073/pnas. 1620211114

[9] Carolus, H., Muzarabani, K. C., Hammoud, C., Schols, R., Volckaert, F. A. M., Barson, M., \& Huyse, T. (2019). A cascade of biological invasions and parasite spillback in man-made Lake Kariba. Science of The Total Environment, 659, 1283-1292. https://doi.org/10.1016/j.scitotenv.2018.12.307

[10] Carpenter, S. R. (2005). Eutrophication of aquatic ecosystems: Bistability and soil phosphorus. Proceedings of the National Academy of Sciences of the United States of America, 102(29), 10002-10005. https://doi.org/10.1073/pnas.0503959102

[11] Scavia, D., David Allan, J., Arend, K. K., Bartell, S., Beletsky, D., Bosch, N. S., Brandt, S. B., Briland, R. D., Daloğlu, I., DePinto, J. V., Dolan, D. M., Evans, M. A., Farmer, T. M., Goto, D., Han, H., Höök, T. O., Knight, R., Ludsin, S. A., Mason, D., ... Zhou, Y. (2014). Assessing and addressing the reeutrophication of Lake Erie: Central basin hypoxia. Journal of Great Lakes Research, 40(2), 226-246. https://doi.org/10.1016/j.jglr.2014.02.004

[12] Bláha, L., Babica, P., \& Maršálek, B. (2009). Toxins produced in cyanobacterial water blooms - toxicity and risks. Interdisciplinary Toxicology, 2(2), 36-41. https://doi.org/10.2478/v10102-009-0006-2

[13] Turner, A. M., \& Chislock, M. F. (2010). Blinded by the stink: Nutrient enrichment impairs the perception of predation risk by freshwater snails. Ecological Applications, 20(8), 2089-2095. https://doi.org/10.1890/10-0208.1

[14] Schindler, D. W. (1974). Eutrophication and Recovery in Experimental Lakes: Implications for Lake Management. Science, 184(4139), 897-899. https://doi.org/10.1126/science.184.4139.897

[15]Lakes-BBMP. (n.d.). Retrieved January 10, 2020, from http://bbmp.gov.in/lakes

[16] Sharma, M. (2014). Water Quality Assessment of the Central Himalayan Lake, Nainital [Research article]. Advances in Environmental Chemistry. https://doi.org/10.1155/2014/473074

[17] Nabar, B., Shirude, M., \& Gupte, A. (2014). Assessment of water quality of urban lakes for recreational purpose in thane district. Journal of Environmental Science, Toxicology and Food Technology, 8, 46-50. https://doi.org/10.9790/240208544650

[18] Bureau of Indian Standards (BIS), 1991. Indian standard specification for drinking water.

[19] K.Raji, P., \& Abraham, M. (2018). COMPARATIVE STUDY OF WATER QUALITY OF DIFFERENT LAKES IN CHENNAI. Rasayan Journal of Chemistry, 11(2), 828-833. https://doi.org/10.31788/RJC.2018.1122005

[20] Gorain, B., Parama, V. R. R., \& Paul, S. (2018). Heavy Metals Contamination in Madiwala and Lalbagh Lakes of Bengaluru, Karnataka: Effect of Idol Immersion Activities. International Journal of Current Microbiology and Applied Sciences, 7(10), 2254-2263. https://doi.org/10.20546/ijcmas.2018.710.260

[21] Barnwal, P., Mishra, S. K., \& Singhal, S. K. (2015). Risk assessment and analysis of water quality in Ramgarh Lake, India.

[22] Road, W., \& Grove, E. (2004). PH Requirements of Freshwater Aquatic Life. 15.

[23] Ahmad, F., Stedtfeld, R. D., Waseem, H., Williams, M. R., Cupples, A. M., Tiedje, J. M., \& Hashsham, S. A. (2017). Most Probable Number-Loop Mediated Isothermal Amplification (MPN-LAMP) for Quantifying Waterborne Pathogens in Less Than 25 Minutes. Journal of Microbiological Methods, 132, 27-33. https://doi.org/10.1016/j.mimet.2016.11.010

[24]Apha-biochemical-oxygen-demand-white-paper.pdf. (n.d.). Retrieved January 11, 2020, from https://betastatic.fishersci.com/content/dam/fishersci/en_US/doc uments/programs/scientific/technicaldocuments/white-papers/apha-biochemical-oxygendemand-white-paper.pdf

[25] Gyure, R. A. (2010). An Eco-friendly, Scaled-down Gram Stain Protocol. Journal of Microbiology \& Biology Education: JMBE, 11(1), 60-61. https://doi.org/10.787/jmbe.v1.i2.144

[26] Bartholomew, J. W., \& Mittwer, T. (1952). THE GRAM STAIN. Bacteriological Reviews, 16(1), 1-29.

[27] Hur, J., Lee, B.-M., Lee, T.-H., \& Park, D.-H. (2010). Estimation of Biological Oxygen Demand and Chemical Oxygen Demand for Combined Sewer Systems Using Synchronous Fluorescence Spectra. Sensors (Basel, Switzerland), 10(4), 2460-2471. https://doi.org/10.3390/s100402460

[28] Brookman, S. K. E. (1997). Estimation of biochemical oxygen demand in slurry and effluents using ultraviolet spectrophotometry. Water Research, 31(2), 372-374. https://doi.org/10.1016/S0043- 
1354(96)00250-3

[29] Verma, N., \& Singh, A. K. (2012). Development of Biological Oxygen Demand Biosensor for Monitoring the Fermentation Industry Effluent. ISRN Biotechnology, 2013. https://doi.org/10.5402/2013/236062

[30] Canelli, E., Mitchell, D. G., \& Pause, R. W. (1976). An improved determination of chemical oxygen demand in water and wastes by a simplified acid dichromate digestion. Water Research, 10(4), 351355. https://doi.org/10.1016/0043-1354(76)90179-2

[31]Rho, T., Choi, S.-H., Kim, E. S., Kang, N. Y., Cho, S. R., Khang, S. H., \& Kang, D.-J. (2018). Optimization of Chemical Oxygen Demand Determination in Seawater Samples Using the Alkaline Potassium Permanganate Method. Ocean Science Journal, 53(4), 611-619. https://doi.org/10.1007/s12601-018-0040-0 